\title{
AN ANALYSIS OF EARLY CAREER TRAINING REQUIREMENTS FOR QUANTITY SURVEYING PROFESSIONALS
}

\author{
Cynthia ChinTian LEE ${ }^{1}$, Srinath PERERA ${ }^{2}$ and Keith HOGG $^{3}$ \\ ${ }^{1}$ School of Engineering and Built Environment, Glasgow Caledonian University, Cowcaddens \\ Road, Glasgow G4 OBA, United Kingdom \\ E-mail: cynthia.lee@gcu.ac.uk \\ ${ }^{2}$ Faculty of Engineering and Environment, Northumbria University, Ellison Place, Newcastle \\ upon Tyne NE1 8ST, United Kingdom \\ E-mail: srinath.perera@northumbria.ac.uk \\ ${ }^{3}$ Faculty of Engineering and Environment, Northumbria University, Ellison Place, Newcastle \\ upon Tyne NE1 8ST, United Kingdom \\ E-mail:keith.hogg@northumbria.ac.uk
}

Received 1 April 2012; accepted 24 August 2012

\begin{abstract}
Early career experience can play a significant part in lifelong professional capability and the support and knowledge gained during the early years of graduate employment can influence future career direction and success. Whilst there are prescribed models of graduate development relative to the surveying professions, for example, those relating to the APC utilised by the RICS, there has been little evaluation in terms of their relative contribution to career success. Through the use of a questionnaire survey, the issue of learning and development for new graduates in their early career, the extent to which new graduates perceive themselves to be competent in various major quantity surveying activities and, the range of graduate training provided by the employer were explored. The main conclusions drawn from the study are that: new graduates exhibit a high level of self-doubt in professional competence; task competence is influenced by frequency of application, years of postgraduate experience and the mode of study taken by graduates in entering the QS profession. There is a difference between training received by graduates working for consultant and contracting employers. Graduates from full time study mode tend to receive more training from their employers compared to part time graduates.
\end{abstract}

KEYWORDS: Assessment of professional competence (APC); Early career training; New graduates; Quantity surveying (QS); Royal Institution of Chartered Surveyors (RICS)

REFERENCE to this paper should be made as follows: Lee, C. C., Perera, S. and Hogg, K. (2013) An analysis of early career training requirements for quantity surveying professionals, International Journal of Strategic Property Management, 17(2), pp. 161-173.

\section{INTRODUCTION}

A particularly challenging task for someone who is 'starting out' in their professional life is to assemble and integrate several kinds of knowledge gained from general experience, education and work. Literature on early professional learning is largely restricted to medi- cine, nursing, teaching and civil engineering (Eraut, 2005). Also, whilst there are well prescribed models of graduate development relative to the surveying professions, for example, those relating to the Assessment of Professional Competence (APC) or from a wide variety of training programmes established by major employers, there has been little evaluation in 
terms of their relative contribution to career success.

Highlighting the potential difficulties of early career learning, research such as Charnley (1999), Godinez et al. (1999) and Greenwood (2000) which looks at the role transition of graduate to staff nurse has shown that the transition from student to newly qualified nurse is stressful and demanding. In the construction arena, research conducted by Love et al. (2001) to establish whether construction managers are able to identify those key skills needed for the future success of the industry indicated that there is a need to improve the skill levels of construction graduates. As learning in the university environment is, in the main, limited to classroom activity, the burden of work-based training for new graduates, recognised as essential to developing full professional competence, would naturally fall upon practitioners. The importance of employer involvement in enhancing professional capability and career satisfaction is clearly central.

Research by Eraut (2003) that looked at learning during the first three years of postgraduate employment, indicated that the support and knowledge gained during the early years of graduate employment is a contributing factor that can influence upon a new graduate's decision to continue to stay in their chosen profession or not. In addition, Gardner (1992) that looked at retention of new graduates showed that dissatisfaction with career advancement opportunities has the largest effect on deciding to quit a profession. Therefore, a better understanding of the factors influencing early career development is a worthwhile objective. Recognition that early career experience can play a significant part in lifelong professional capability and satisfaction is of relevance to the Quantity Surveying (QS) profession. It is also of interest for the RICS as the professional body to understand the apparent hesitance of some graduates to pursue professional body membership (Perera, 2006). In the study by Perera (2006) it indicates that nearly $80 \%$ of graduates now seek employment with contractors and hence possibly may end up with membership of allied professional bodies such as Chartered Institute of Building (CIOB).

This research will add to the understanding of early career development within the QS profession through the following specific objectives:

1. To explore various types of support needed for early career learning;

2. To investigate the current practices used in the management and implementation of early career learning in the QS profession;

3. To establish the extent to which the progress of learning is influenced by a range of possible factors, including; employer type; employer workload, corporate ethos and mission, client base; size of employer, location of employer, workplace environment;

4. To explore the impact of method of graduate entry on early career learning via full-time, part-time and sandwich course study.

This research will also inform new graduates of ways in which to enhance professional development in their early career and improve our understanding of graduate retention and levels of participation within the RICS. The approach will also provide a basis for a strategic review of the way new graduates are trained in the workplace. The overall strategy of the research is to adopt the concepts of 'learning' and 'knowledge transfer', amongst others, to investigate the issues associated with the early career development of QS graduates.

\section{EARLY CAREER DEVELOPMENT}

Previous research has provided some understanding of the meaning and significance of the 'career' as a fundamental part of personal development. The concept of 'career' as suggested by Arthur et al. (1999) is to explore individual identity and social institutions, work and other experiences. Extending this, as careers unfold, there will be a change in the way we present ourselves to others, treated by 
others and interact with others (Barley, 1989). The process by which individuals pick up or cultivate a certain set of capabilities, connections, confidence, and cognition due to their work experiences at a particular employer is called career imprinting (Higgins, 2005), the focus of this research.

A challenge exists in matching academic provision with professional needs is well versed and employers have expressed concerns, for example, on the apparent gap between engineering education and professional practice (Dillon, 1998; Florman, 1997; Pascail, 2006). In accepting this position, a better understanding of the needs of new graduates in the workplace will help employers in their provision of training and educators in improving programme design. This perspective is supported by Coupland (2004) who focuses on the tools and practices of interaction, identified that the company career structure described by some participants as lacking in explicit stages and suggested that the company should take on a greater role in the individual's career.

As opposed to the traditional image of a linear and organizationally bound journey where graduates expect employers to play a greater role in an individual's career development (Coupland, 2004), career has also been conceptualised as having no boundary (Arthur and Rousseau, 1996; Arthur et al., 2005). In this alternative view, individuals are expected to self-manage their own careers rather than rely on organisational direction (Hall and Chandler, 2005; Hall and Mirvis, 1995). According to the Social Cognitive Career Theory (Lent, 2005), the model proposes that people are more likely to take actions to achieve their goals if they have access to environmental (organisational) support and resources relevant to the pursuit of these goals. However, the model of proactive behaviour (Crant, 2000) indicates that an individual's disposition or personality will influence the extent to which they take the initiative to engage in career management behaviours and achieve career satisfaction. Thus, the onus of developing one's career is on the individual to take up a range of activities outside day to day work that are geared towards personal development or ongoing employability. However, the provision of opportunity for career imprinting should still lie with the employer.

'Career' is linked to learning "in a virtuous cycle" (Arthur et al., 1999). Learning is represented as an on-going individual process, driven by the life-long learning imperative and focused on the development of learning and career meta-skills (Hall, 2002; Waterman et al., 1994) and is treated as an unquestioned value in itself (Gherardi, 1999). Learning is unequivocally identified as a proxy for career success (Weick, 1996). Organisational support for career development is also called "organisational career management" or "organisational sponsorship" and refers to the programs, processes and assistance provided by organisations to support and enhance their employees' career success (Ng et al., 2005; Orpen, 1994). Training refers to the formal provision of learning experiences at work (Mallon and Walton, 2005). In this research, participants were asked to provide data on aspects of organisational career management and to indicate the extent to which various types of training were provided by their employers.

Competency is defined by Holmes and Joyce (1993) as action, behaviour or outcome which a person should be able to demonstrate, or the ability to transfer skills and knowledge to new situations within an occupational area. In this study, competency is defined as an identifiable aspect of prospective work behaviour attributable to the quantity surveyor that is expected to contribute positively to organizational effectiveness in the construction industry. This is in line with the RICS who identifies three types of QS competencies categorised as mandatory, core and optional with a three level attainment of each competency (RICS, 2006). In a study on nurses' competencies, Meretoja et al. (2004) found a positive relationship between competency and frequency of use. This survey explores this relationship in the context of quantity surveying graduates in the construction industry. 


\section{RESEARCH METHOD}

According to Denzin and Lincoln (1994), the researcher's ontological, epistemological and methodological premises (assumptions) are contained under the research paradigm. These assumptions are also the core components of the research process given by Grix (2002) in his diagram 'The interrelationship between the building blocks of research'. There are various research methodologies which one may employ, some of them belong to the deductive approach and others to the inductive approach. The context of this research falls under positivism research paradigm and a deductive approach was taken where numerical and statistical process was used to answer questions about early career quantity surveying graduates.

Ontological assumptions are concerned with what we believe constitutes social reality (Blaikie, 2000). According to Tuli (2010), ontological questions in social science research are related to the nature of reality and there are two broad and contrasting positions: objectivism and constructivism. The position held in this research is objectivism and the philosophical basis is that the world exists and is knowable and researchers can use quantitative methodology to discover it (Cohen et al., 2000). Research findings under this strand are usually represented quantitatively in numbers (Tuli, 2010; Mutch, 2005; Cohen et al., 2000).

Epistemology focuses on the knowledge gathering process and is concerned with developing new models or theories. Two epistemological positions were identified by Tuli (2010): positivism and interpretivism. According to Neuman (2003, cited in Tuli, 2010), positivism sees social science as an organised method for combining deductive logic with precise empirical observations of individual behaviour in order to discover and confirm a set of probabilistic causal laws that can be used to predict general patterns of human activity. Findings from this research are taken from a positivism perspective and are explained in quantitative terms; multivariate analysis and techniques for statistical predictions are among the classic contributions of this type of research.

\section{QUESTIONNAIRE DESIGN AND SAMPLING}

Survey research methodology was adopted in this research to investigate the competency level and training of quantity surveying graduates in their early careers. The research questionnaire was designed using variables identified during exploratory studies.

The survey population in this study is recent graduates with not more than 3 years of working experience as quantity surveyors. Non Probability Sampling, whereby the research subjects are chosen for specific attributes rather than from a random selection, is adopted in this study as the research primarily looks at the early career of quantity surveying graduates. Rather than taking a random cross section of the population to be studied, a "small numbers of people with specific characteristics, behaviour or experience are selected to facilitate broad comparisons between certain groups that the researcher thinks likely to be important" (Walker, 1985) were selected in this research. In this case, only recent graduates from the RICS database were chosen. The sample frame therefore consisted of all recent graduates between years 2006 and 2008 registered with the RICS irrespective of their discipline. In essence, this is a limitation in the sample frame, as the sample frame provided by the RICS did not differentiate graduates based on their discipline. In order to ensure that recent non-cognate graduates (non QS graduates but are working as quantity surveyors) were not missed out, questionnaires were sent to all recent graduates regardless of their discipline.

In Section 1 of the questionnaire, general information was sought from the respondents on the years of experience, their role and the mode of study to acquire their qualification. In the following Sections 2, 3 and 4 of the questionnaire, using a Likert scale of 1 to 5 , each of the respondents were asked to rate their competency relating to core QS activities, the frequency in which those activities were carried out in their job and the extent to which various types of support were given by their 
Table 1. Calculated Cronbach Alpha coefficient in the research survey

\begin{tabular}{lll}
\hline $\begin{array}{l}\text { Section in the } \\
\text { questionnaire } \\
\text { survey }\end{array}$ & \begin{tabular}{l} 
Item / Variable \\
\hline 2
\end{tabular} & $\begin{array}{l}\text { Cronbach } \\
\text { Alpha } \\
\text { coefficient }\end{array}$ \\
\hline 3 & $\begin{array}{l}\text { The extent to which respondents feel they are competent in various QS } \\
\text { activities }\end{array}$ & 0.862 \\
& $\begin{array}{l}\text { The extent to which respondents frequently carry out various QS } \\
\text { activities }\end{array}$ & 0.814 \\
& $\begin{array}{l}\text { The extent to which the respondents' company provide various QS } \\
\text { training/support }\end{array}$ & 0.845 \\
\hline
\end{tabular}

employer. As Likert scales with odd number response points are arguably empirically more valid than forced-choice scales (Ray, 1990), a 5-point Likert scale was used, being more cost and time effective than a seven-point scale (Munchi, 1990). A key feature of the questionnaire is the use of self-evaluation in determining levels of graduate competences. Although this pragmatic approach may raise doubt over the validity of the data relating to this aspect of the research, previous work by Lee and Quazi (2001) found that scores from a well-constructed self-assessment questionnaire closely correlate with actual scores made by independent evaluators.

\section{PRELIMINARY DATA ANALYSIS}

A total of 4430 email survey requests which make up the population, were sent to recent RICS graduate members who graduates between years 2006 and 2008 in the UK requesting them to respond to the online questionnaire; of which 425 surveys were completed online indicating a response rate of $10 \%$. Given that, the normal response rate for most postal questionnaire surveys of the construction industry is $20-30 \%$ (Akintoye and Fitzgerald, 2000); a $10 \%$ response rate was considered low. However, based on Bartlett et al. (2001)'s calculation to determine an appropriate sample size in survey research for a population exceeding 4000 is 198 . Therefore, the received response of 425 satisfies this requirement. In addition, the low response rate could be explained by the fact that questionnaires were sent to all recent graduates from the RICS database and only respondents working as quantity surveyors were targeted and encouraged to reply.

The survey responses were first tested for the internal consistency or reliability of the data variables using Cronbach alpha tests. Ideally, the Cronbach alpha coefficient of a scale should be above 0.7 (Pallant, 2005) and the nearer the result of alpha value to 1 - preferably 0.8 or above - the more internally reliable the scale is (Bryman and Cramer, 2005). The Cronbach alpha coefficients calculated in this survey are tabulated in Table 1.

It is suggested by Cronbach (1951) that if the scale shows poor reliability, then individual items within the scale must be re-examined and modified or completely changed as needed. The reliability test is especially important when derivative variables are intended to be used for subsequent predictive analyses. The survey responses for this research indicate a Cronbach alpha coefficient of more than 0.7 for Sections 2, 3 and 4 of the questionnaire. This suggests that the data variables are reliable.

\section{FINDINGS AND DISCUSSION}

Respondents were asked to indicate within the questionnaire survey the total number of years respondents have been working as Quantity Surveyors after obtaining their degree. The level of work experience of the sample is indicated in the analysis of the distribution (see Table 2). 
Table 2. Number of questionnaires received from various groups of respondents

\begin{tabular}{ll}
\hline No of years of experience & No. of response \\
\hline Less than 1 year & 101 \\
1 Year & 44 \\
2 Years & 93 \\
3 Years & 54 \\
More than 3 years & 133 \\
Total & 425 \\
\hline
\end{tabular}

As the research targets early career QS graduates (i.e. less than 3 years of graduation) the analysis found that there were 133 graduates exceeding this period. This leaves a data sample of 292 as valid for further analysis. It should also be pointed out that this data set is still valid as it clearly exceeds the minimum requirement of 198 for the population size concerned (Bartlett et al., 2001).

The following analysis and discussion considers the findings relating to: QS activities and corresponding perceptions of competence, and; the types of training support and their extent of use.

\section{QS Activity and Perceptions of Competence}

A list of professional QS activities, which are basically the primary duties carried out by quantity surveyors, was provided in the questionnaire survey which incorporated a wide range of QS activities, deduced from the RICS Assessment of Competency Guide for Quantity Surveying and Construction pathway (RICS, 2006). Respondents were asked to indicate their own perception of competence and the frequency of engagement with regard to each of the QS activities listed in Table 3.

From the survey results as indicated in Table 3, the five QS activities which respondents carry out most frequently and perceived themselves to be most competent at are:

1) interim valuation of construction work,

2) preparation of final accounts,

3) cost management to ensure budget compliance,

4) preparation of tender reports,

5) management and preparation of variation accounts.

Table 3. Number of respondents who indicated a Likert Scale of 5 for the QS activities which they frequently carry out and perceive themselves to be most competent

QS Activities

Preparation of final accounts

Cost management to ensure budget compliance

Preparation of tender reports

Management and preparation of variation accounts

Preparation of schedules of works or Bills of Quantities involving measurement and estimation

Preparation of feasibility studies

Advising clients and negotiation with contracting parties in contract administration

Recommendation of a suitable procurement route

Application of value management

Preparation of life cycle costing data and advice
Number of respondents indicating a Likert Scale of 5 for the QS activities which they perceive themselves to be most competent of
Number of respondents indicating a Likert Scale of 5 for the frequency of carrying out the QS activities

$\begin{array}{ll}132 & 134 \\ 92 & 61 \\ 73 & 88 \\ 69 & 51 \\ 61 & 77 \\ 39 & 27 \\ 34 & 27 \\ 31 & 29 \\ 26 & 12 \\ 26 & 13 \\ 2 & 3\end{array}$

134 
The frequency of use indicated here is very much in line with usual activities performed by early career graduate quantity surveyors. It shows that more advanced activities such as life cycle costing or recommendation of suitable procurement route where experience judgement and intuition play a vital role are activities that they are less exposed to.

The association between the respondents' self-perception of competence and frequency of carrying out the range of QS activities was investigated using Spearman correlation coefficient. The closer the coefficient $R$ is to +1 or -1 , the stronger the likely correlation. A perfect positive correlation is +1 and a perfect negative correlation is -1 . The strength of correlation of $r=0.813$ was obtained in this case which indicates that there was a significant positive correlation, suggesting a strong relationship between perception of competence and frequency of use.

Gibbons et al. (1994) affirmed that the creation of knowledge is through practice. Graham and McKenzie (1995), illustrated that the best learning occurs in real life and for the majority of new graduates, learning will be achieved by 'doing'. The concept 'practice makes perfect' is widely recognised in the industry and in applying this tenet in this situation, it is possible to assume that frequency of use will result in improved competence. Conversely, activities such as life cycle costing, value management and giving procurement advice to clients, in that they are not frequently carried out by recently graduating quantity surveyors, and therefore, will suffer from reduced levels of competence. It is also recognised that the development of new graduates is influenced by factors such as the job content, timing of projects, the attitude of the individual and relationship with line manager (Graham and McKenzie, 1995). Thus, this reduced exposure to some aspects of practice could contribute to underdevelopment of certain areas of knowledge and skills which may be reflected in future hesitance in application.

The job scope of a quantity surveyor will directly influence his/her skills. This is illus- trated by a comparison made between the services provided by quantity surveyors in private consultancy practice and contracting companies by Male (1990). It indicates services such as feasibility studies, cost planning, tender documentation are carried out more frequently by quantity surveyors working in consultancy practice than in contracting companies. As the QS activities listed in this research were generic, comparison between the competency and frequency in carrying out the QS activities with the role respondents play i.e. whether they are working in consultant companies or contractors is beyond the scope of this study.

\section{Provision of training support}

Respondents were also asked to identify their role in their current job; whether they are working as a consultant QS, contractor's QS, sub-contractor's QS or others (see Table 4). Of the 292 respondents with not more than 3 years' work experience as QS, 10 were working for sub-contractors and the 30 identified under 'Others' are working on jobs such as employer agent, development executive, commercial surveyor, contract administrator.

Table 4. Number of questionnaires received based on roles played by respondents

\begin{tabular}{ll}
\hline $\begin{array}{l}\text { Role of respondents in their } \\
\text { current job }\end{array}$ & No. of response \\
\hline Consultant & 164 \\
Contractor & 88 \\
Sub-contractor & 10 \\
Others & 30 \\
Total & 292 \\
\hline
\end{tabular}

In our analysis, the 10 respondents working for sub-contractors have been included within the category of respondents working as contractor QS reflecting their commercial stand point whilst the 30 respondents identified as 'Others' are included in the consultant QS category, reflecting a client focused advisory function. Thus, respondents were categorised under consultant or contractor QS depending on their employment.

Additionally, respondents were requested to indicate the extent of various training support 
Table 5. Percentage of respondents indicating a Likert Scale of 4 or 5 for the types of training given by their employers

\begin{tabular}{|c|c|c|c|}
\hline Types of training provided by employer & $\begin{array}{l}\text { Consultant } \\
(\mathrm{n}=194)\end{array}$ & $\begin{array}{l}\text { Contractor } \\
(\mathrm{n}=98)\end{array}$ & Difference \\
\hline Help from senior colleagues & $70 \%$ & $56 \%$ & $13 \%$ \\
\hline Help from assigned mentor & $53 \%$ & $42 \%$ & $11 \%$ \\
\hline Provision of in-house seminars & $49 \%$ & $38 \%$ & $11 \%$ \\
\hline Time allowance for attending CPD events & $47 \%$ & $38 \%$ & $9 \%$ \\
\hline Provision of structured Continuing Professional Development (CPD) & $56 \%$ & $48 \%$ & $8 \%$ \\
\hline $\begin{array}{l}\text { Dissemination of information on the latest development / legislation } \\
\text { in the construction industry }\end{array}$ & $39 \%$ & $32 \%$ & $7 \%$ \\
\hline
\end{tabular}

provided by their employer as illustrated in Table 5 using a Likert scale between 1 and 5 .

The total number of respondents under each employment category who indicated a Likert scale of 4 or 5 for each types of training support given by their employers were divided by the total number of respondents under each employment category and expressed in percentage in Table 5.

There is a clear indication of greater satisfaction in the types of employer support given to graduates working for consultants as compared to contractors. This is a direct comparison between the two types of employers. An in-depth analysis indicates that for most types of support (with the exception of dissemination of information on the latest development/legislation in the construction industry) given by their employers, approximately $50 \%$ or more of the respondents employed by consultants indicate a Likert Scale of 4 or 5 . The picture is significantly poor when graduates employed by contractors are examined with only two types of support above or approaching 50\% (Table 5).

A comparison between the employment category of the respondents and each type of training support received by the respondents in Table 5 indicates that help from senior colleagues, 'whereby a more experienced person helps a less experienced person develop their capacity' (Provident, 2005), is a preferred approach for employers in the training of new graduates. This preferred method of training is outlined by Kalinauckas and King (1994) as coaching and is important for enhancing the performance of new graduates.
The relationship between the extent of training respondents received from their employer and the role they played was analysed using the Kruskal Wallis test.

Table 6. Kruskal Wallis test result on the relationship between role and training received by respondents from their employer

\begin{tabular}{lcccl}
\hline & $\begin{array}{l}\text { Mean } \\
\text { Rank }\end{array}$ & df & $x^{2}$ & $\begin{array}{l}\text { Significance } \\
(\rho)\end{array}$ \\
\hline $\begin{array}{l}\text { Training } \\
\text { received }\end{array}$ & & 1 & 8.158 & 0.004 \\
Consultant & 151.30 & & & \\
Contractor & 121.91 & & & \\
\hline
\end{tabular}

* results are statistically significant at $p<0.05$

As indicated in Table 6, a significance level of 0.004 was obtained. As any level $<0.05$ is considered significant the value 0.004 suggests that there is a significant relation in the training received by respondents whether they are a consultant QS or contractor QS. An examination of the difference in the extent of training received by consultant and contractor QS as indicated in Table 5 and the mean rank calculated in Table 6; where the higher mean rank was associated with more training received. It indicates a difference in the amount of training received between graduates working for consultant and contractor. The mean rank of the extent of training received by respondents working as consultant QS is 151.30 and is more than respondents who are working for contractor with a mean rank of 121.91. This indicates that consultant QS received more training than QS working for contractor. 


\section{Impact of years of post-graduation experience}

The Kruskal Wallis test was also applied to the questionnaire survey data in considering the following relationship:

- Years of experience and the respondents' level of competency for various QS activities.

- Years of experience and the respondent's frequency of carrying out the various QS activities.

- Years of experience and the extent of training the respondents' received.

Table 7. Kruskal Wallis test result on the relationship between years of experience and competency, frequency and training

\begin{tabular}{lcccl}
\hline & $\begin{array}{l}\text { Mean } \\
\text { rank }\end{array}$ & df & $x^{2}$ & $\begin{array}{l}\text { Signifi- } \\
\text { cance }(\rho)\end{array}$ \\
\hline Competency & & 3 & 13.890 & 0.003 \\
Less than 1 year & 125.55 & & & \\
1 year & 114.28 & & & \\
2 years & 148.35 & & & \\
3 years & 165.94 & & & \\
Frequency & & 3 & 7.481 & 0.058 \\
Less than 1 year & 121.05 & & & \\
1 year & 119.94 & & & \\
2 years & 144.56 & & & \\
3 years & 149.15 & & & \\
Training & & 3 & 3.504 & 0.320 \\
Less than 1 year & 149.73 & & \\
1 year & 144.09 & & & \\
2 years & 127.82 & & & \\
3 years & 142.06 & & \\
\hline
\end{tabular}

* results are statistically significant at $p<0.05$

The results (as shown in Table 7) indicate a significance level of $0.003,0.058$ and 0.320 for all 3 relationships. As any level $<0.05$ is considered significant and only the relationship between years of experience and competency is less than 0.05 , it suggests that there are no differences between frequency of use of QS activities and training compared to early years of experience. However, there is a difference between perceived competency and early years of experience. This suggests that respondents perceived themselves to be more competent the more years of experience they have.

The mean rank obtained from the Kruskal Wallis test in Table 7 compares the competency level, the frequency in which various QS activities were carried out and the training received by respondents with different levels of early experience. The higher values suggest respondents with that particular years of experience feel more competent or carry out various QS activities more frequently or receive more training. An inspection of the mean rank suggests that respondents with 3 years work experience perceive themselves to be more competent than the other respondents who have had less than 3 years work experience. This observation could be due to the fact that people with less years of experience in quantity surveying have yet to accumulate enough work experience which they think is adequate for them to be competent in their activities. Very often, tacit knowledge is accumulated and acquired through 'learning by-doing' (Mascitelli, 2000). Such form of non-formal learning is termed 'implicit learning'; where there is no intention to learn and no awareness of learning at the time it takes place (Eraut, 2003).

Additionally, a very thorough inspection of the mean rank suggests that respondents with less than 1 year experience and 3 years experience tend to carry out various QS activities more frequently than the others.

Further inspection of the mean rank in Table 7 between years of experience and training suggest that employers tend to focus their training on respondents with less than 1 year, 1 year and 3 years' experience. It indicates that there is lesser emphasis on the year 2 trainees. The greater emphasis on training for respondents with 3 years' work experience could be because most such new graduates are close to their APC for Chartered Surveyor status.

\section{Mode of Study}

Respondents were requested to indicate the mode of study in which they followed to enter into the QS profession. The distribution of respondents based on the mode of study is shown in the Table 8 below: 
Table 8. Mode of study respondents take to enter the QS profession

\begin{tabular}{ll}
\hline $\begin{array}{l}\text { Mode of study taken by respondents } \\
\text { to enter the QS profession }\end{array}$ & $\begin{array}{l}\text { No. of } \\
\text { respondents }\end{array}$ \\
\hline 5 years / 6 years part-time study & 60 \\
3 years full-time study & 37 \\
4 years sandwich course & 75 \\
2 years distance learning & 31 \\
Others & 86 \\
Missing data & 3 \\
Total & 292 \\
\hline
\end{tabular}

A relatively large number of responses in the 'Others' category reflect the range of academic entry routes, including graduates from Scottish universities who gain their qualification through 4 years full-time study, graduates holding HND qualification, graduates who did a 2 years part-time masters conversion course, etc. Therefore, it can be assumed that QS qualifications can be obtained through various routes and forms of education.

The respondents were then categorised under 'Full time' and 'Part-time' study and the group of respondents with 'Others' responses were categorised under 'Full time' or 'Parttime' based on the responses specified by them.

Mann-Whitney test illustrated in Table 9 was carried out to look at the differences be- tween respondents who entered the QS profession via full time or part-time study and to compare the training support they received from their employers. Using a non-parametric 0.95 confidence interval, a significance level of 0.054 was obtained. As the value is only 0.004 more than 0.05 , the result suggests that there is very little difference in the training support received by respondents entering the QS profession via full time or part-time mode of study. However, an examination of the mean rank where the higher mean rank was associated with more training received, it indicated that respondents who entered the QS profession through part-time study receive more training support from their employers than respondents who entered the QS profession through full-time study.

Similarly, Mann-Whitney test was conducted to look at the relationship between the respondents' competency level and the mode of study they take to enter the QS profession via full-time or part-time study.

As illustrated in Table 10, a significance value of 0.002 , which is less than 0.05 was obtained, indicating that there is a significant difference in the competency level and mode of study. As a higher mean rank was associated with higher competency, the mean rank

Table 9. Mann-Whiteney test result on the differences between mode of study and training

\begin{tabular}{llllllll}
\hline & $\mathrm{N}$ & $\begin{array}{l}\text { Mean } \\
\text { rank }\end{array}$ & Sum of ranks & $\begin{array}{l}\text { Mann- } \\
\text { Whitney U }\end{array}$ & $\begin{array}{l}\text { Wilcoxon } \\
\text { W }\end{array}$ & $\begin{array}{l}\text { Z } \\
(\rho)\end{array}$ & $\begin{array}{l}\text { Significance } \\
(\rho)\end{array}$ \\
\hline Training & & & & 8256.500 & 19431.500 & -1.927 & 0.054 \\
Part-time study & 149 & 130.41 & 19431.50 & & & \\
Full-time study & 128 & 149.00 & 19071.50 & & & \\
Total & 277 & & & & & \\
\hline
\end{tabular}

* results are statistically significant at $\mathrm{p}<0.05$

Table 10. Mann-Whiteney test result on the differences between mode of study and competency

\begin{tabular}{llllllll}
\hline & N & $\begin{array}{l}\text { Mean } \\
\text { rank }\end{array}$ & Sum of ranks & $\begin{array}{l}\text { Mann- } \\
\text { Whitney U }\end{array}$ & $\begin{array}{l}\text { Wilcoxon } \\
\text { W }\end{array}$ & $\begin{array}{l}\text { Z } \\
\text { Significance } \\
(\rho)\end{array}$ \\
\hline Competency & & & & 7297.000 & 15425.000 & -3.118 & 0.002 \\
Part-time study & 147 & 151.36 & 22250.00 & & & \\
Full-time study & 127 & 121.46 & 15425.00 & & & \\
Total & 274 & & & & & \\
\hline
\end{tabular}

* results are statistically significant at $p<0.05$ 
Table 11. Comparison of self-perceived competence level between graduates from full-time and sandwich course

\begin{tabular}{lll}
\hline QS Activities & $\begin{array}{l}\text { Number of respondents } \\
\text { graduate from full-time } \\
\text { course indicating a }\end{array}$ & $\begin{array}{l}\text { Number of respondents } \\
\text { graduate from } \\
\text { sandwich course } \\
\text { indicating a Likert }\end{array}$ \\
& $\begin{array}{l}\text { QS activities which they } \\
\text { perceive themselves to be } \\
\text { most competent of }\end{array}$ & $\begin{array}{l}\text { Scale of 5 for the } \\
\text { frequency of carrying } \\
\text { out the QS activities }\end{array}$ \\
\hline Interim valuation of construction work & 43 & 51 \\
Preparation of final accounts & 36 & 40 \\
Cost management to ensure budget compliance & 28 & 29 \\
Preparation of tender reports & 34 & 26 \\
Management and preparation of variation accounts & 29 & 27 \\
Preparation of schedules of works or Bills of Quantities & 17 & 19 \\
involving measurement and estimation & & 12 \\
Preparation of feasibility studies & 21 & 12 \\
Advising clients and negotiation with contracting parties & 19 & 12 \\
in contract administration & 22 & 12 \\
Recommendation of a suitable procurement route & 17 & 2 \\
Application of value management & 2 & \\
Preparation of life cycle costing data and advice & &
\end{tabular}

indicated that respondents who enter the QS profession via part-time study tend to perceive themselves to be more competent in the QS activities listed in the survey than respondents who complete their education via full-time study. This could be due to the fact that quantity surveyors on full-time work and part-time study tend to be learning while on their job and so feel more competent in the QS activities. However, most QS programmes now tend to include modules on 'reflective practice' and 'work based learning' with industrial mentors as a measure to compensate for such issues.

In addition, a comparison on the self-perceived competency level between graduates from full-time and sandwich courses was made in Table 11. As compared to graduates from full-time courses, graduates from sandwich courses tend to feel more competent in carrying out the following QS duties:

- Interim valuation of construction work;

- Preparation of final accounts;

- Cost management to ensure budget compliance;

- Preparation of tender reports;
- Management and preparation of variation accounts;

- Preparation of schedules of works or Bills of Quantities involving measurement and estimating.

A reason to explain the fact that there is less significant difference in other QS activities listed in Table 11 is that these activities are often carried out by more experienced QSs.

\section{CONCLUSION AND FURTHER RESEARCH}

This research informs the wider audience of the perceived competencies of new graduates in their early career, the influence of post-graduate experience and mode of study on competencies and training of new graduates. The research also provides a basis for a strategic review of the way new graduates are trained in the workplace and provide an insight for the RICS in future re-structuring of graduate pathway and its training and development regime.

Findings of this study show that there is a strong relationship between perceived compe- 
tence and frequency of carrying out the QS activities. Early graduates perceived themselves to be more competent on the QS activities that were carried out more frequently in their course of work. There is a significant disparity between the extent of support given by consultant and contractor employers. The private sector consultants tend to provide better support for early career quantity surveyors they employ. Additionally, graduates who entered the QS profession via part-time study receive more training from their employers than those who entered the QS profession through fulltime study. This study also reveals that graduates with more years of experience or those who entered the QS profession via part-time study tend to perceive themselves to be more competent in QS activities and tend to have a greater degree of confidence. Employers utilise a range of support methods with a preference for mentoring through experienced staff. The development of new graduates is somewhat subject to opportunity and timing of projects.

This survey has identified a number of issues which are worthy of further exploration, which is being undertaken through extended analysis of the data obtained for this research and additional survey activity. As this research only explore the self-perceived competence of early career graduates, it would be beneficial to also explore the employers' view on the competence of new graduates. A recent report produced by Perera and Pearson (2011) analyses the achievement of competencies by graduate QSs from both the industry and academic perspectives. The next stage of this research will identify the specific types of support early graduates require from their employers and explore whether these training support requirements differ between graduates working for consulting or contracting employers. Additionally, the difference in competency level and frequency of carrying out QS activities by surveyors working in consultancy practice and contracting companies is also an area worth exploring. Further research will be carried out to map the level of competence of QS graduates with that of the RICS Quantity Surveying pathway.

\section{REFERENCES}

Akintoye, A. and Fitzgerald, E. (2000) A survey of current cost estimating practices in the UK, Construction Management and Economics, 18, pp. 161-172. http:// dx.doi.org/10.1080/014461900370799

Arthur, M. and Rousseau, D. (Eds.) (1996) The boundaryless career: A new employment principle for a new organizational era. New York: Oxford University Press.

Arthur, M. B., Inkson, K. and Pringle, J. K. (1999) The new careers: Individual action and economic change. London: Sage Publications.

Arthur, M. B., Khapova, S. N. and Wilderom, C. P. M. (2005) Career success in a boundaryless career world, Journal of Organizational Behavior, 26(2), pp. 177-202. http://dx.doi.org/10.1002/job.290

Barley, S. R. (1989) Careers, identities and institutions: The legacy of the Chicago School of Sociology. In: Arthur, M. B., Hall, D. T. and Lawrence, B. S. (eds.), Handbook of career theory. Cambridge: Cambridge University Press, pp. 41-65.

Bartlett, J. E., Kotrlik, J. W. and Higgins, C. C. (2001) Organisational research: Determining appropriate sample size in survey research, Information Technology, Learning and Performance Journal, 19(1), pp. 43-50.

Blaikie, N. (2000) Designing social research. Cambridge: Polity.

Bryman, A. and Cramer, D. (2005) Quantitative data analysis with SPSS release 12.0: A guide for social scientists. Routledge (UK)

Charnley, E. (1999) Occupational stress in the newly qualified staff nurse, Nursing Standard, 13(29), pp. 33-36.

Cohen, L., Manion, L. and Morrison, K. (2000) Research methods in education. $5^{\text {th }}$ ed. London: Routledge Falmer.

Coupland, C. (2004) Career definition and denial: A discourse analysis of graduate trainees' accounts of career, Journal of Vocational Behaviour, 64(3), pp. 515-532. http://dx.doi.org/10.1016/j.jvb.2003.12.013

Crant, J. M. (2000) Proactive behaviour in organizations, Journal of Management, 26(3), pp. 435-462. http:// dx.doi.org/10.1177/014920630002600304

Cronbach, L. J. (1951) Coefficient alpha and the internal structure of tests, Psychometrika, 16(3), pp. 297-334. http://dx.doi.org/10.1007/BF02310555

Denzin, N. and Lincoln, Y. (Eds.) (1994) Handbook of qualitative research. Thousand Oaks, CA: Sage.

Dillon, C. (1998) Engineering education: Time for some new stories, Engineering Science and Education Journal, 7(4), pp. 188-192. http://dx.doi.org/10.1049/ esej: 19980410

Eraut, M. (2003) Learning during the first three years of postgraduate employment - The LiNEA project. In: ECER 2003 Conference, Padua, August 2003.

Eraut, M. (2005) Learning during the first three years of postgraduate employment - The LiNEA project. [Online] Full research report. Available at: http://www. esrcsocietytoday.ac.uk/ [accessed 4 January 2008]

Florman, S. (1997) Non-technical studies for engineers: The challenge of relevance, European Journal of Engineering Education, 22(3), pp. 249-258. http:// dx.doi.org/10.1080/03043799708923457

Gardner, D. L. (1992) Conflict and retention of new graduates, Western Journal of Nursing Research, 14(1), pp. 76-85. 
Gherardi, S. (1999) Learning as problem-driven or learning in the face of mystery?, Organization Studies, 20(1), pp. 101-123. http://dx.doi. org/10.1177/0170840699201005

Gibbons, M., Limoges, C., Nowothy, H., Schwartzman, S., Scott, P. and Trow, M. (1994) The new production of knowledge. London: Sage Publications.

Godinez, G., Schweiger, J. Gruver, J. and Ryan, P. (1999) Role transition from graduate to staff nurse: A qualitative analysis, Journal for Nurses in Staff Development, 15(3), pp. 97-110.

Graham, C. and McKenzie, A. (1995) Delivering the promise: Developing new graduates, Education and Training, 37(2), pp. 33-40. http://dx.doi. org/10.1108/00400919510084559

Greenwood, J. (2000) Critique of the graduate nurse: An international perspective, Nurse Education Today, 20(1), pp. 17-23. http://dx.doi.org/10.1054/ nedt.2000.0424

Grix, J. (2002) Introducing students to the generic terminology of social research, Politics, 22(3), pp. 175-186. http://dx.doi.org/10.1111/1467-9256.00173

Hall, D. T. (2002) Careers in and out of organizations. Sage Publications, CA: Thousand Oaks.

Hall, D. T. and Chandler, D. E. (2005) Psychological success: When the career is a calling, Journal of Organizational Behaviour, 26(2), pp. 155-176.

Hall, D. T. and Mirvis, P. H. (1995) The new career contract: Developing the whole person at midlife and beyond, Journal of Vocational Behaviour, 47(3), pp. 269-289. http://dx.doi.org/10.1006/jvbe.1995.0004

Higgins, M. C. (2005) Career imprints: Creating leaders across an industry. Jossey-Bass.

Holmes, L. and Joyce, P. (1993) Rescuing the useful concept of managerial competence: From outcomes back to process, Personnel Review, 22(6), pp. 37-52. http:// dx.doi.org/10.1108/00483489310048972

Kalinauckas, P. and King, H. (1994) Coaching: Realising the potential. Chartered Institute of Personnel \& Development.

Lee, P. M. and Quazi, H. A. (2001) A methodology for developing a self-assessment tool to measure quality performance in organisations, International Journal of Quality \& Reliability Management, 18(2), pp. 118141. http://dx.doi.org/10.1108/02656710110379066

Lent, R. W. (2005) A social cognitive view of career development and counselling. John Wiley \& Sons Inc.

Love, P. E. D., Haynes, N. S. and Irani, Z. (2001) Construction managers expectations and observations of graduates, Journal of Managerial Psychology, 16(8), pp. 579-593. http://dx.doi.org/10.1108/ EUM0000000006301

Male, S. (1990) Professional authority, power and emerging forms of 'profession' in quantity surveying, Construction Management and Economics, 8(2), pp. 191204. http://dx.doi.org/10.1080/01446199000000016

Mallon, M. and Walton, S. (2005) Career and learning: The ins and the outs of it, Personnel Review, 34(4), pp. 468 487. http://dx.doi.org/10.1108/00483480510599789

Mascitelli, R. (2000) From experience: Harnessing tacit knowledge to achieve breakthrough innovation, Journal of Innovation Management, 17(3), pp. 179193. http://dx.doi.org/10.1111/1540-5885.1730179

Meretoja, R., Isoaho, H. and Leino-Kilpi, H. (2004) Nurse competence scale: Development and psychometric testing, Journal of Advanced Nursing,
47(2), pp. 124-133. http://dx.doi.org/10.1111/j.13652648.2004.03071.x

Munchi, J. (1990) A method for constructing Likert scales. [Online] Available at: http://munchi.sonoma.edu/ working/likert.html

Mutch, C. (2005) Doing educational research: A practitioner's guide to getting started. Wellington: NZCER Press.

Neuman, W. L. (2003) Social research methods: Qualitative and quantitative approached. $5^{\text {th }}$ edition. Boston: Allyn and Bacon.

Ng, T. W. H., Eby, L. T., Sorensen, K. L. and Feldman, D. C. (2005) Predictors of objective and subjective career success: A meta-analysis, Personnel Psychology, 58(2), pp. 367-408. http://dx.doi.org/10.1111/ j.1744-6570.2005.00515.x

Orpen, C. (1994) The effects of organisational and individual career management on career success, International Journal of Manpower, 15(1), pp. 27-37. http:// dx.doi.org/10.1108/01437729410053617

Pallant, J. (2005) SPSS Survival Manual: a step by step guide to data analysis using SPSS for Windows (version 12). Open University Press.

Pascail, L. (2006) The emergence of the skills approach in industry and its consequences for the training of engineers, European Journal of Engineering Education, 31(1), pp. 55-61. http://dx.doi. org/10.1080/03043790500428965

Perera, S. and Pearson, J. (2011) Alignment of professional, academic and industrial development needs for quantity surveyors: Post recession dynamics. [Online] RICS Education Trust funded research report, UK. Available at: http://www.rics.org/site/scripts/ download_info.aspx?fileID=11013\&categoryID $=523$ [accessed 29 May 2012]

Perera, R. S. (2006) Views of prospective graduate surveyors on their professional career plans. Final Report, RICS NI, August 2006.

Provident, I. M. (2005) Mentoring: A role to facilitate academic change, Internet Journal of Allied Health Sciences and Practice, 3(2). [Online] Available at: http:// ijahsp.nova.edu

Ray, J. J. (1990) Acquiescence and problems with forcedchoice scales, Journal of Social Psychology, 130(3), pp. 397-399. http://dx.doi.org/10.1080/00224545.199 0.9924595

RICS (2006) Assessment of competency guide for quantity surveying and construction pathway. [Online] RICS Education and Training. Available at: http://www. rics.org/site/download_feed.aspx?fileID=165\&fileExt ension=PDF

Tuli, F. (2010) The basis of distinction between qualitative and quantitative research in social science: Reflection on ontological, epistemological and methodological perspectives, Ethiopian Journal of Education and Science, 6(1), pp. 97-108.

Walker, R. (1985) Applied qualitative research. Gower Press.

Waterman, R. H., Waterman, J. A. and Collard, B. A. (1994) Toward a career-resilient workforce, Harvard Business Review, July/August, pp. 87-95.

Weick, K. E. (1996) Enactment and the boundaryless career: Organizing as we work. In: Arthur, M. and Rousseau, D. (eds.), The boundaryless career: A new employment principle for a new organizational era. New York: Oxford University Press, pp. 40-57. 